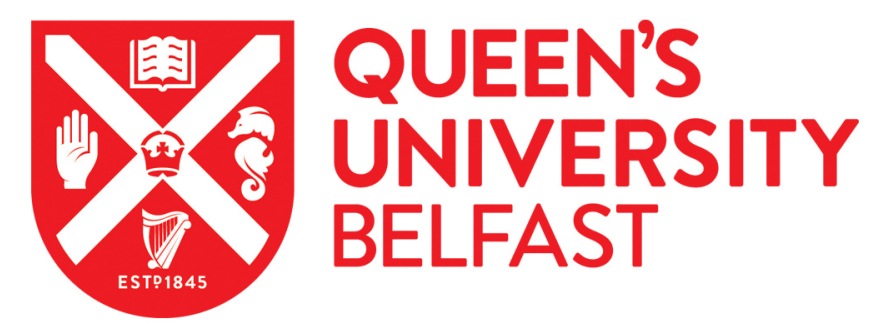

\title{
Destabilising institutions to make healthcare more equitable: clinicians, educators, and researchers co-producing change
}

Dornan, T., Kearney, G. P., \& Pyörälä, E. (2020). Destabilising institutions to make healthcare more equitable: clinicians, educators, and researchers co-producing change. Medical teacher.

https://doi.org/10.1080/0142159X.2020.1795102

Published in:

Medical teacher

Document Version:

Peer reviewed version

Queen's University Belfast - Research Portal:

Link to publication record in Queen's University Belfast Research Portal

Publisher rights

Copyright () 2020 Informa UK Limited, trading as Taylor \& Francis.

This work is made available online in accordance with the publisher's policies. Please refer to any applicable terms of use of the publisher.

\section{General rights}

Copyright for the publications made accessible via the Queen's University Belfast Research Portal is retained by the author(s) and / or other copyright owners and it is a condition of accessing these publications that users recognise and abide by the legal requirements associated with these rights.

Take down policy

The Research Portal is Queen's institutional repository that provides access to Queen's research output. Every effort has been made to ensure that content in the Research Portal does not infringe any person's rights, or applicable UK laws. If you discover content in the Research Portal that you believe breaches copyright or violates any law, please contact openaccess@qub.ac.uk. 


\title{
Destabilising institutions to make healthcare more equitable: clinicians, educators, and researchers co-producing change
}

\author{
Tim Dornan, Gráinne P Kearney, and Eeva Pyörälä
}

\begin{abstract}
Disturbances and conflicts in everyday medical work ... challenge the medical social system to understand and manage complexity, identify the dynamics of contradictions, and utilize them in emancipatory transformations. (Engeström and Pyörälä 2020 - this issue)
\end{abstract}

If medicine's purpose is to optimise care and education's purpose is to optimise learning, medical education research's purpose is to optimise learning to care. Elite academics use a linear, hierarchical model to achieve this: they produce research outcomes, which educators translate into educational outcomes, and jobbing clinicians translate into health outcomes. So far, so simple; but, according to expert opinion, unlikely to improve healthcare. (Teodorczuk et al. 2017) Eight articles in this issue of Medical Teacher use Engeström's seminal theory of Expansive Learning (part of a broader framework known as CulturalHistorical Activity Theory [CHAT] (Engeström and Pyörälä 2020)) to show that the translational model can be theoretically simplistic and practically ineffective. Collectively, the authors ('we') theorise and empirically validate a conjoint practice of caring, learning, and research, co-produced by its own stakeholders. This commentary explains why hallowed institutions need to change if the scholarship of medical education is to achieve its full potential.

We use CHAT to identify 'structurally accumulated tensions' in care, education, and research, resulting from the unopposed effects of neoliberal politics, 'evidence', and/or theory. We show adverse consequences of medical education's obsession with assessment. We show how practice communities, which risk stagnating amidst irreconcilable tensions, can co-produce 'possibility knowledge'. Rather than teaching students and doctors to be competent but not necessarily capable, we show how undergraduate, postgraduate, and continuing education can help patients and practitioners learn together to practise well. We describe hierarchical social positioning, fragmented practice communities, and irrational variation in practice. We identify tensions and ruptures between specialties, and between specialism and generalism. This complexity challenges the weakest link in the translational model of contemporary medical education: transition into practice. For patients to benefit, we argue, the whole contemporary institution of medical education needs to embrace complexity.

CHAT (Engeström and Pyörälä 2020) is orientated towards social justice: a fair and equal society in which each individual matters. CHAT provides a theoretical platform to make social boundaries permeable, involve all stakeholders, and harness 'fluid' relationships between them to drive change (Varpio and 
Teunissen 2020). It treats social contexts and the activities within them as inseparable. Whilst this confounds the simplicity of the translational model, it allows non-linear relationships between cause and effect in complex systems (Regehr 2010) to produce large outputs from small inputs. The politics of this type of change is not 'top-down'; rather, it emerges from stakeholders' co-participation in determining and pursuing goals (e.g. Morris et al. 2020). We made real live patients, who 'more than anything else arouse involvement, effort, emotion, excitement and frustration among front-line staff' (Engeström 2018) the object ${ }^{1}$ of the collective activities of clinical care, education, and research. This generated the design concept for a new undergraduate curriculum (Bleakley 2020). It helped socially disadvantaged Brazilian women be treated respectfully, rather than used as tools for obstetric residents' learning; a highly effective, continuing systemic change resulted. (Grilo Diniz et al. 2020) Acknowledging the stultifying effect of standardizing human behaviour for Objective Structured Clinical Examinations (OSCEs) opened up possibilities to release latent energy for change in medical education. (Reid et al. 2020)

Subtle changes in the subject of educational activity can also catalyse change; for example, a simple intervention changed medical students from observers, becoming competent for practice, into residents-inwaiting, becoming capable by participating in practice (Gillespie et al. 2020). A humble mediating tool - a pen filled with purple ink - mediated students' identity change. As residents-in-waiting, they now responded to nurses' requests to write orders so that patient care could proceed (Gillespie et al. 2020). Written instruments, another example of a mediating tool, had a pivotal role in improving collaboration between GPs and specialists, and between the many practitioners caring for elderly people with complex needs (Engeström and Pyörälä 2020; Meijer et al. 2020). Official rules made by government and insurers impeded collaboration between Dutch specialist and generalist care providers. (Meijer et al. 2020). Unofficial rules also influenced educational activity; for example, by perpetuating medical students' unsafe participation in practice (Gillespie et al. 2020) and trivialising patient-centred behaviour (Reid et al. 2020). Regulators had a strong, potentially negative effect on a national practice community by positioning themselves as proxies for real patients (Gillespie et al. 2020; Meijer et al. 2020; Reid et al. 2020).

The importance of division of labour is obvious when one considers the proliferation of professions and specialities that surround patients. It is here that the practical ability of CHAT-inspired research to expand learning and care comes into its own. Far from elite researchers taking primary responsibility for education development, patients, care-givers, students, managers and other interested parties work together to research and implement change. This takes place in purposefully planned Change Laboratory interventions, with which we improved multi-agency care, (Engeström and Pyörälä 2020) obstetric residency and medical student placement education, (Morris et al. 2020) and collaboration between specialists and generalists

\footnotetext{
${ }^{1}$ We have used italics to denote the six main components of any activity system: activity, object, subject, tools, rules, community, and division of labour.
} 
(Meijer et al. 2020). CHAT provided a lens through which to examine interprofessional collaboration, in all its on-the-ground fluidity, and to show why followership is as important to leadership as the reverse (Varpio and Teunissen 2020). CHAT regards such tensions as both inescapable and, when clearly understood, a potent driver of change. This results, not from bringing multi-voiced communities into perfect harmony, but from synchronising dissonance so that stakeholders can 'collectively form concepts in the wild'. (Engeström and Pyörälä 2020)

The eminent sociologist, Dorothy Smith, encouraged researchers to examine the social 'institutions' (which does not just mean official organisations or buildings), which organise peoples' worlds and everyday work. She urged critical scrutiny of how institutions' politically elevated positions 'on the $14^{\text {th }}$ Floor'(Smith 2008) afford power to organise people's work whilst remaining detached from on-the-ground actualities. CHAT helped us turn tensions between politicised institutions and clinicians' real work into energy for change: students labouring to show regulators they were competent were transformed into trainee doctors becoming capable of caring for patients; (Gillespie et al. 2020; Reid et al. 2020) and generalists and specialists, divided from one another by the competing demands of government and insurers, became collaborators in patient care (Meijer et al. 2020). CHAT helped a number of authors change the famously patriarchal institution of Obstetrics and Gynaecology. They addressed the bullying and harassment of trainees (Morris et al. 2020) and the abuse of women for training purposes (Grilo Diniz et al. 2020), and turned interprofessional rivalry into a collaborative focus on the best interests of women in labour (Varpio and Teunissen 2020).

This critique of institutions invites two further questions: why have such tensions arisen in the humane pursuit of education for clinical care, and where should we go from here? Karl Marx argued that a fundamental contradiction between the 'exchange value' (what you can sell something for) and 'use value' (how useful it is in your own hands) affects activities in all societies. (Engeström 2018) Two articles illustrate this contradiction using the example of OSCEs in contemporary medical education. (Gillespie et al., 2020; Reid et al., 2020) At present, psychometricians calculate precise cut-off levels, above which students can exchange an OSCE score for a medical qualification and the right to earn money; medical schools exchange evidence that their assessments are reliable for the right to graduate students; and regulators exchange oversight of reliable exams for the power to regulate medical education. Reliable measurement dominates a 'commodity market' of medical education. Students and patients, though, are idiosyncratic human beings, not commodities. An OSCE score can have a high value in a regulated market and yet be useless to new doctors and the real patients they treat.

The global dominance of neoliberalism explains why it may not be too far-fetched to suggest that the institution of medical education is, as the previous paragraph suggests, misdirecting its effort.

Neoliberalism is guided by the ideology that the 'market', and hence market-based solutions, are the most 
efficient and effective way to address public sector problems. (Kearney et al., 2019) 'New Public Management' ([NPM]; Hood 1991, Griffith and Smith 2014) puts into practice neoliberal principles (Kearney et al., 2019), which include: hands-on professional management; applying private-sector principles - including explicit standards and measures of performance - to professional practice; a stress on results rather than procedures; and promoting competition to cut costs.(Hood, 1991) We hope this explanation of contemporary ideology will help clinicians and educators understand the 'mission creep', whereby politicians have turned 'professionalism' into staffing the production lines of state-controlled and private for-profit institutions.

We used the emotive word 'destabilising' in our title to remind readers of the tendency for stable institutions to fossilise, and for their stability to become an unassailable 'normal'. We have shown how communal destabilisation for patient benefit can restore professional vitality rather than the anarchy that conservative thinkers might fear. We suggest that a conjoint practice of caring, learning, and research is achievable. Our humane institution should reconnect with its core values, shun NPM, and allow patients and learners to arouse our involvement, effort, and excitement.

\section{References}

Bleakley A. 2020. Embracing Ambiguity: Curriculum Design and Activity Theory, Med Teach, In Press.

Engeström Y. 2018. Expertise in transition. Expansive learning in medical work. Cambridge: Cambridge University Press

Engeström Y, Pyörälä E. 2020. Using Activity Theory to transform medical work and learning. Med Teach, In Press.

Gillespie H, McCrystal E, Reid H, Conn R, Kennedy N, Dornan T. 2020. The pen is mightier than the sword. Reinstating patient care as the object of prescribing education. Med Teach, In Press.

Griffith, A.I., and Smith, D. (eds.) (2014) Under new public management. Institutional ethnographies of changing front-line work. Toronto: University of Toronto Press

Grilo Diniz CS, Castro Bussadori JC, Lemes Luana B, Dantas Moisés EC, de Campos Prado CA, , McCourt C. 2020. A Change Laboratory for maternity care in Brazil: pilot implementation of MotherBaby Friendly Birthing Initiative. Med Teach, In Press. 
Hood C. 1991. A public management for all seasons? Public Adm. 69: 3-19.

Kearney GP, Corman MK, Hart ND, Johnston JL, Gormley GJ. 2019. Why Institutional Ethnography?

Why now? Institutional ethnography in health professions education. Perspectives on Medical Education 8 (1): $17-24$

Meijer L, de Groot E, Honing-de Lange G, Kearney G, Schellevis F, Damoiseaux R. 2020. Transcending boundaries for collaborative patient care. Med Teach, In Press.

Morris C, Reid AM, Ledger A, Teodorczuk A. 2020. Expansive learning in medical education: putting Change Laboratory to work. Med Teach, In Press.

Regehr G. 2010. It's NOT rocket science: rethinking our metaphors for research in health professions education. Med Educ. 44(1): 31-9.

Reid H, Gormley G, Dornan T, Johnston J. 2020. Harnessing insights from an activity system - OSCEs past and present expanding future assessments. Med Teach in Press.

Smith, D. E. (1987) 'The Everyday World As Problematic: A Feminist Sociology.' Boston, USA: Northeastern University Press

Smith DE. 2008. From the 14th floor to the sidewalk: Writing sociology at ground level. Sociol Inq. 78(3): 417-422.

Varpio L. Teunissen P. 2020. Reformulating leadership in interprofessional healthcare Teams: How knotworking requires followership. Med Teach, In Press. 